\title{
ACKNOWLEDGMENTS
}

thank my agent Kate Johnson at MacKenzie Wolf for her steadfast support, superior work ethic, keen eyes, and literary smartness.

The very same goes to my editor Miranda Martin at Columbia University Press.

These two brilliant women recognize the value of lost histories and silenced voices. They appreciate the humanistic in science and the emotional in facts. They look beyond the artificial division between experts and laypeople. They advocate for non-Western, non-masculine authors. Working with them has been an absolute pleasure.

Thanks also go to my colleague Deborah Murray, who introduced me to the charming Meadowlark retirement community; my colleague Elizabeth Dodd, who gave me invaluable insight in conceiving a big picture for the book; and my colleague Katherine Karlin, who patiently read proposal and chapter drafts, encouraged, guided, and helped in every way she could. I am very lucky to have you all in my life. 


\section{$X$ ACKNOWLEDGMENTS}

Thank you, too, to the very capable editorial and production team at Columbia University Press and its partner who saw this book through various stages of production: Brian Smith for tying up various loose ends, Ben Kolstad and Sue McClung for copyediting, Leslie Kriesel for coordinating, and other behind-the-scene folks. Your professionalism inspires me.

And, of course, thank you to my husband, who puts up with my long hours bound to the desk, who never hesitates to challenge me, and who is prouder of me than I am of myself. 
MIND THIEF 
